\title{
Influence of Different Spherical Binary Plasmonic NPs on HTM Layer in Methyl Ammonium Lead Triiodide Solar Cell
}

\author{
Cliff Orori Mosiori ${ }^{1}$, Walter Kamande Njoroge ${ }^{1}$, Lawrence Otieno Ochoo ${ }^{1}$ \\ ${ }^{1}$ Kenyatta University \\ P. 0. Box 43844-00100, Nairobi, Kenya
}

DOl: $10.22178 /$ pos.50-4

LCC Subject Category: TP155-156

Received 03.09.2019

Accepted 27.09.2019

Published online 30.09.2019

Corresponding Author:

Cliff Orori Mosiori

corori@tum.ac.ke

(c) 2019 The Authors. This article

is licensed under a Creative

Commons Attribution 4.0 License
Abstract. Methylammonium lead triiodide perovskite solar cells have attracted huge research interest. Its optoelectronic properties are competing with those of silicon wafers. It is a hybrid absorber with a direct band gap of about $1.53 \mathrm{eV}$ with good light-absorption capability appropriate for optoelectronic applications. A typical perovskite solar cell HTML layer rarely incorporates $\mathrm{ZnO}$ or $\mathrm{Cu}_{2} \mathrm{O}$ or $\mathrm{TiO}_{2}$ nanoparticles to increase charge carrier transport. These $\mathrm{ZnO}, \mathrm{Cu}_{2} \mathrm{O}, \mathrm{TiO}_{2}$ nanoparticles can be introduced into the HTM layer to modify its PSCs efficiency and performance. These nanoparticles are direct band gap binary semiconductors with a wide band gap energy range of $2.17 \mathrm{eV}$ to $3.37 \mathrm{eV}$ respectively which can lead to higher transport mobility and enhanced HTM nanostructured layer. In this paper, two model solar cell having a ITO/TiO $2 / \mathrm{CH}_{3} \mathrm{NH}_{3} \mathrm{Pbl} / 3 / \mathrm{P} 3 \mathrm{HT} / \mathrm{Ag}$ and ITO/TiO $/$ /Ag: $\mathrm{CH}_{3} \mathrm{NH}_{3} \mathrm{Pbl}_{3} / \mathrm{P} 3 \mathrm{HT} / \mathrm{Ag}$ structures were proposed, geometrically modelled and simulated using SCAPS-1D software. Their HTM layer (composed of $\mathrm{P} 3 \mathrm{HT}$ ) was doped with $\mathrm{ZnO}, \mathrm{Cu}_{2} \mathrm{O}$, and $\mathrm{TiO}_{2}$ nanoparticles respectively to determine their influence on PCEs of this solar cells. It was revealed that starting from undoped $\mathrm{P} 3 \mathrm{HT}$ layer all through the $\mathrm{Cu}_{2} \mathrm{O}, \mathrm{ZnO}$ to $\mathrm{TIO}_{2}$ doped layers, efficiency reduced from $13.123 \%$ and $9.071 \%$ respectively; fill factor (FF) also reduced from $69.4 \%$ to $48.9 \%$ for the doped $\mathrm{CH} 3 \mathrm{NH} 3 \mathrm{Pbl} 3$ perovskite solar cell while efficiency of doped $\mathrm{CH}_{3} \mathrm{NH}_{3} \mathrm{Pbl}_{3}$ perovskite solar cell reduced from $13.033 \%$ and $9.091 \%$, the fill factor (FF) also reduced from $66.4 \%$ to $52.9 \%$ respectively. It was noted that the solar cell employing P3HT undoped layer had the best performance and concluded that introducing nanoparticles onto $\mathrm{P} 3 \mathrm{HT}$ layer has a negative impact on the performance of CH3NH3Pbl3 perovskite solar cell.

Keywords: Plasmonic Oscillations; hybrid perovskite; SCAPS-1D software; photon absorption; Computer Simulation Technology.

\section{INTRODUCTION}

Modern thin-film solar cells have reduced material consumption [2] and fabrication costs. However, a major limitation facing hybrid perovskite thin-film solar cells is its poor photon absorption [1]. It is documented that light-trapping can be increased by increasing the optical path length inside a film, but how to implement it remains a mirage [4]. Plasmonic structures can modify the excitations of localized surface plasmon to improve photon absorption [5]. Surface plasmon is a collective oscillation of free exciting electrons of metallic nanoparticles $[5,7,9]$ which can be used to enhance optical absorption through scattering and near-field concentration photons depending on particle shape [11], size [15], inter-particle distance [22], optical resonance [25], material nature [34] and type of coupled systems avail- able [29]. However, plasmon coupling only occurs when closely spaced nanoparticles have their associated electron oscillations influencing its local field affect electron oscillations of neighbouring particles [28, 31, 33]. Many noble metallic nanoparticles have been tested for plasmonic coupling. These include gold $(\mathrm{Au})$, copper $(\mathrm{Cu})$, silver $(\mathrm{Ag})$ and aluminium $(\mathrm{Al})$ nanoparticles $[9,12,18]$. Their dipole and quadrupole plasmon resonances can be described qualitatively using spherical nanoparticles [20, 26]. They have already shown a red-shift in total absorption flux enhancement and tunable localized surface plasmon resonance. The role of near-field coupling, resonance, scattering and transmission of light have been investigated too using $\mathrm{Ag}$ nanoparticles $[6,11,27]$. An enhancement factor of 2.3 in external quantum efficiency 
at $1100 \mathrm{~nm}$ wavelength, a sevenfold enhancement of light absorption and a 16-fold enhancement for $1250 \mathrm{~nm}$ using Ag nanoparticles have been reported by some publications $[14,18,25$, 33]. This paper focuses on the doping the HTM layer and its influence on the efficiency of methylammonium lead triiodide solar cells as simulated using SCAPS-1D software at AM1.5G solar radiation that employs FDTD, FEM, and FIT methods.

SCAPS-1D simulation software. SCAPS-1D is a onedimensional solar cell simulation software that employs three coupled differential equations. The first equation is the Poisson's equation given as (1):

$$
\begin{aligned}
& \frac{\partial}{\partial x}\left(\left(-\varepsilon_{(x)}\right) \frac{d \varphi}{d x}\right)= \\
& \quad=q\left[\begin{array}{c}
p_{(x)}-n_{(x)}-N_{d(x)}^{+}-N_{a(x)}^{-}+ \\
+p_{t(x)}-n_{t(x)}
\end{array}\right],
\end{aligned}
$$

where $\psi$ is electrostatic potential, $q$ is electron charge, $p$ is free holes, $n$ is free electrons, $p_{t}$ is trapped holes, $n_{t}$ is trapped electrons, $\mathrm{N}_{\mathrm{a}}{ }^{-}$is ionized acceptor-like doping concentration, and $\mathrm{N}_{\mathrm{d}^{+}}$ is ionized donor-like doping concentration [24, 30].

The second equation (2) is the continuity equation for holes as $[2,5,11]$ :

$$
\begin{aligned}
\frac{d p_{n}}{d t} & =G_{p}-\frac{p_{n}-p_{n o}}{\tau_{p}}-p_{n} \mu_{p} \frac{d \xi}{d x}- \\
- & \mu_{p \xi} \frac{d p_{n}}{d x}+D_{p} \frac{\partial_{p_{n}}^{2}}{\partial x^{2}}
\end{aligned}
$$

while the 3 equations is the continuity equation for electrons as:

$$
\begin{aligned}
\frac{d n_{p}}{d t} & =G_{n}-\frac{n_{p}-n_{p o}}{\tau_{n}}-n_{p} \mu_{n} \frac{d \xi}{d x}- \\
- & \mu_{n} \xi \frac{d n_{p}}{d x}+D_{n} \frac{\partial_{n_{p}}^{2}}{\partial x^{2}}
\end{aligned}
$$

where $G$ is generation rate, $\xi$ is permittivity while $D$ is the diffusion coefficient.
Computer Simulation Technology. Computer Simulation Technology (CST) is a 3D simulation software used to numerically calculate optical properties required for many applications that include plasmonic solar cells, electromagnet metamaterials and antennas when exposed to an electromagnetic field. It is a 3D EM solver that solves Maxwell's equation in the time domain with Finite integration method (FIT) and frequency domain with the Finite element method (FEM) by incorporating FDTD and FDFD techniques. CST software is a Multiphysics software that employs FIT, FEM, FDTD and FDFD to simulate designed plasmonic nanostructures of various PV devices. CST is a 3D simulation software used in order to attain accurate simulation results under the absorption profile and internal quantum efficiency as a function spatial position, photon density and frequency. It employs FDTD technique to evaluate electron transport, series resistance and fill factor enhancement, distribution profile of the photons absorbed and also electron-hole pair recombination rate. It is a time domain technique used to solve Maxwell's equations in differential form over a grid-based domain in a single simulation by calculating electric field, $E$, and magnetic field, $B$ for time irrespective of the designed 1D, 2D and 3D models expressed as $[14,15,23]$ :

$$
\begin{aligned}
\frac{\partial}{\partial t} B(\hat{R}, t) & =-\nabla \times E(\hat{R}, t)-J_{m}(\hat{R}, t) \\
\frac{\partial}{\partial t} D(\hat{R}, t) & =\nabla \times H(\hat{R}, t)-J_{e}(\hat{R}, t)
\end{aligned}
$$

It reveals nano-structural shapes, material types, dielectric environments, array pitches and particle locations for the source of light scattering. Its optical computational power provides the final power conversion efficiency of plasmonic solar cells. FEM available in CST software and it is used to calculate solutions to partial differential and integral Maxwell's equations. It is suitable for simulating irregular shaped geometrical models for optical devices as it provides information even of large dtime and frequency domains small elements in regions where fields may abruptly change. It can also simulate larger elements in less important and unexpected electromagnet regions. 


\section{METHODOLOGY}

Device Structures. A plasmonic model solar cell was designed containing silver nanoparticle doped and undoped methylammonium lead triiodide $\left(\mathrm{CH}_{3} \mathrm{NH}_{3} \mathrm{PbI}_{3}\right)$ as a perovskite absorber layer. The solar cell had five layers as a glass cover (protection purposes), an anode (transparent conducting film), substrate (glass), $n$-type compact layer, absorber layer $\left(\mathrm{Ag}: \mathrm{CH}_{3} \mathrm{NH}_{3} \mathrm{PbI}_{3}\right.$ and/or $\mathrm{CH}_{3} \mathrm{NH}_{3} \mathrm{PbI}_{3}$ ), P3HT (p-type hole transport layer) and a cathode (silver) designed according to [35] as shown in Figure 1.

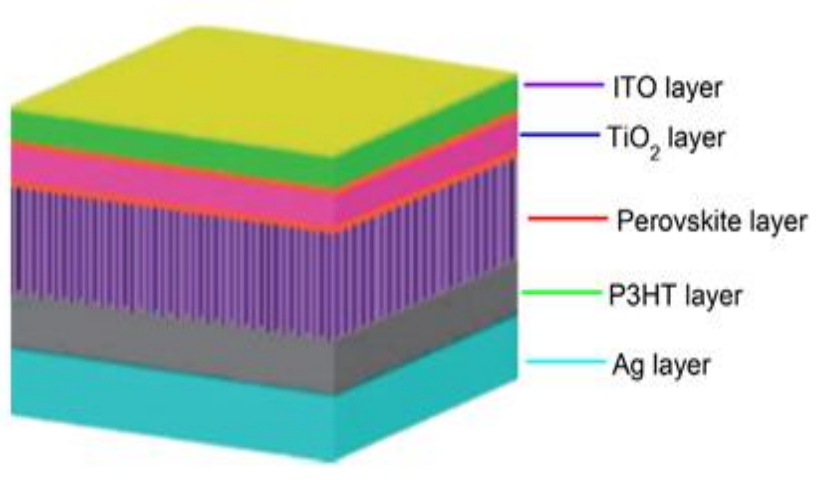

Figure $1-\mathrm{CH}_{3} \mathrm{NH}_{3} \mathrm{Pbl}_{3}$ device structure

It was modeled as shown in Figure 2. All the models were considered to be solid-state planar heterojunction $p$-i-n solar cells with low p-typedoped $\mathrm{CH}_{3} \mathrm{NH}_{3} \mathrm{PbI}_{3}$ sandwiched between the $n$ type ETM (compact $\mathrm{TiO}_{2}$ ) and $p$-type HTM (P3HT) layers according to [15].
Simulations were performed using light that propagated along $z$ direction, through $\mathrm{TiO}_{2}$, $\mathrm{CH}_{3} \mathrm{NH}_{3} \mathrm{PbI}_{3}$ and entering $\mathrm{P} 3 \mathrm{HT}$ hole transporting layer in that order.

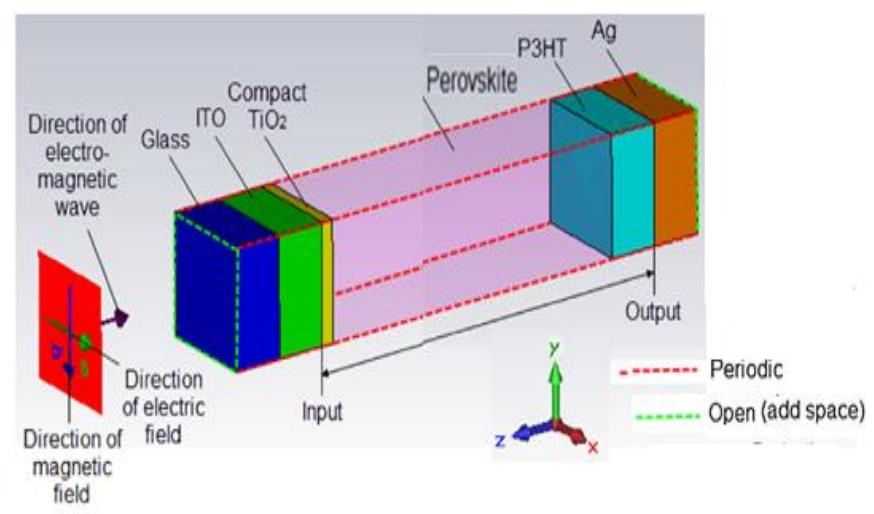

Figure $2-\mathrm{CH}_{3} \mathrm{NH}_{3} \mathrm{Pbl}{ }_{3}$ device structure

The same design was maintained for the one with or without the silver nanoparticle in its perovskite layer. The $p$-type hole transport (P3HT) layer also modelled as doped with $\mathrm{ZnO}$, $\mathrm{Cu}_{2} \mathrm{O}$ and $\mathrm{TiO}_{2}$ nanoparticles separately and simulated using CST (microwave studio). Numerical simulation using SCAPS-1D simulation software was carried out to analysed the electrical parameters and the PCEs of the resulting solar cells. Table 1 and Table 2 shows the model parameter of the solar cells that were simulated.

Table 1 - Layer arrangement in $\mathrm{CH}_{3} \mathrm{NH}_{3} \mathrm{Pbl}_{3}$ device structure

\begin{tabular}{|c|c|c|c|}
\hline No & Dopant NPs & Dopant on (HTM) & Device layer structure \\
\hline $\mathrm{A} 1$ & & P3HT & $\mathrm{ITO} / \mathrm{TiO}_{2} / \mathrm{CH}_{3} \mathrm{NH}_{3} \mathrm{PbI}_{3} / \mathrm{P} 3 \mathrm{HT} / \mathrm{Ag}$ \\
\hline $\mathrm{A} 2$ & $\mathrm{ZnO}$ & P3HT:ZnO & $\mathrm{ITO} / \mathrm{TiO}_{2} / \mathrm{CH}_{3} \mathrm{NH}_{3} \mathrm{PbI}_{3} / \mathrm{P} 3 \mathrm{HT}: \mathrm{ZnO} / \mathrm{Ag}$ \\
\hline $\mathrm{A} 3$ & $\mathrm{Cu}_{2} \mathrm{O}$ & P3HT: $\mathrm{Cu}_{2} \mathrm{O}$ & $\mathrm{ITO} / \mathrm{TiO}_{2} / \mathrm{CH}_{3} \mathrm{NH}_{3} \mathrm{PbI}_{3} / \mathrm{P} 3 \mathrm{HT}: \mathrm{Cu}_{2} \mathrm{O} / \mathrm{Ag}$ \\
\hline $\mathrm{A} 4$ & $\mathrm{TiO}_{2}$ & P3HT:TiO ${ }_{2}$ & $\mathrm{ITO} / \mathrm{TiO}_{2} / \mathrm{CH}_{3} \mathrm{NH}_{3} \mathrm{PbI}_{3} / \mathrm{P} 3 \mathrm{HT}: \mathrm{TiO}_{2} / \mathrm{Ag}$ \\
\hline
\end{tabular}

Table 2 - Layer arrangement in $\mathrm{CH}_{3} \mathrm{NH}_{3} \mathrm{Pbl}_{3}$ device structure

\begin{tabular}{|c|c|c|c|}
\hline No & Dopant NPs & Dopant on (HTM) & Device layer structure \\
\hline B1 & - & P3HT & $\mathrm{ITO} / \mathrm{TiO}_{2} / \mathrm{Ag} \mathrm{CH}_{3} \mathrm{NH}_{3} \mathrm{PbI}_{3} / \mathrm{P} 3 \mathrm{HT} / \mathrm{Ag}$ \\
\hline $\mathrm{B} 2$ & $\mathrm{ZnO}$ & P3HT:ZnO & $\mathrm{ITO} / \mathrm{TiO}_{2} / \mathrm{Ag} \mathrm{CH}_{3} \mathrm{NH}_{3} \mathrm{PbI}_{3} / \mathrm{P} 3 \mathrm{HT}: \mathrm{ZnO} / \mathrm{Ag}$ \\
\hline B3 & $\mathrm{Cu}_{2} \mathrm{O}$ & P3HT:Cu 20 & ITO/TiO $/ \mathrm{Ag}_{2} \mathrm{CH}_{3} \mathrm{NH}_{3} \mathrm{PbI}_{3} / \mathrm{P} 3 \mathrm{HT}: \mathrm{Cu}_{2} \mathrm{O} / \mathrm{Ag}$ \\
\hline B4 & $\mathrm{TiO}_{2}$ & P3HT:TiO 2 & $\mathrm{ITO} / \mathrm{TiO}_{2} / \mathrm{Ag}: \mathrm{CH}_{3} \mathrm{NH}_{3} \mathrm{PbI}_{3} / \mathrm{P} \mathrm{HT}: \mathrm{TiO}_{2} / \mathrm{Ag}$ \\
\hline
\end{tabular}

Device Simulation. Two simulation software were used in this work. The SCAPS-1D simulation software was used to numerically simulate photovoltaic cell analysis while other parameters were simulated using Computer Simulation Technology (CST) software. These are easy to use software's available from authorized vendors. 
The solar cell models in Table 1 and Table 2 were simulated.

Choice of simulation parameters. The material optical parameters used in SCAPS-1D simulation were selectively picked from published articles by [35] and a number of supporting optoelectronic theories. The other optical constant and absorption coefficients for both $\mathrm{CH}_{3} \mathrm{NH}_{3} \mathrm{PbI}_{3}$ and Ag: $\mathrm{CH}_{3} \mathrm{NH}_{3} \mathrm{PbI}_{3}$ were obtained from [16]. A summary of some of these optical parameters are as tabulated in tables 1 . It was adopted that the defect density of $1 \times 10^{10} \mathrm{~cm}^{-3}$, electron hole and thermal velocity of $1.0 \times 10^{7} \mathrm{~cm} / \mathrm{s}$, donor density, $\left(N_{D}\right)$ of zero $(0)$, defect reference energy level was taken above $E_{\mathrm{v}}$ while energy level reference to $0.7 \mathrm{e} \mathrm{V}$ respectively. Finally, energetic distribution and reference point for defect energy level $\left(E_{t}\right)$ were assumed to be single and above the highest $\mathrm{E}_{\mathrm{v}}$ respectively when simulating the active layers $\left(\mathrm{CH}_{3} \mathrm{NH}_{3} \mathrm{PbI}_{3}, \mathrm{Ag}: \mathrm{CH}_{3} \mathrm{NH}_{3} \mathrm{PbI}_{3}\right)$ and perovskite/P3HT interface layers. Numerical simulation was finally performed.

Table 3 - Parameters for SCAPS-1D simulation

\begin{tabular}{|l|c|c|c|}
\hline Parameters & Unit & $\mathrm{Ag}: \mathrm{CH}_{3} \mathrm{NH}_{3} \mathrm{PbI}_{3}$ & $\mathrm{CH}_{3} \mathrm{NH}_{3} \mathrm{PbI}_{3}$ \\
\hline Bandgap & $\mathrm{eV}$ & 1.662 & 1.711 \\
\hline Thickness & $\mathrm{nm}$ & 420 & 420 \\
\hline $\begin{array}{l}\text { Dielectric } \\
\text { constant }\end{array}$ & $\mathrm{eV}$ & 4.20 & 10 \\
\hline $\begin{array}{l}\text { Electron } \\
\text { affinity }\end{array}$ & $1 / \mathrm{cm}^{3}$ & $1.0 \times 10^{18}$ & $2.25 \times 10^{18}$ \\
\hline $\begin{array}{l}\text { Density of } \\
\text { States (CB) }\end{array}$ & $1 / \mathrm{cm}^{3}$ & $1.0 \times 10^{18}$ & $1.0 \times 10^{18}$ \\
\hline $\begin{array}{l}\text { Density of } \\
\text { States (VB) }\end{array}$ & $\mathrm{cm}^{2} / \mathrm{Vs}$ & 1.6 & 2.20 \\
\hline $\begin{array}{l}\text { Electron } \\
\text { mobility }\end{array}$ & $\mathrm{cm}^{2} / \mathrm{Vs}$ & 1.6 & 2.20 \\
\hline Hole mobility & $1 / \mathrm{cm}^{3}$ & $3.2 \times 10^{15}$ & $1.0 \times 10^{18}$ \\
\hline $\left.\begin{array}{l}\text { Acceptor } \\
\text { density, (N }\end{array}\right)$ & $\mathrm{cm}^{2}$ & $1.0 \times 10^{-16}$ & $1.0 \times 10^{-13}$ \\
\hline $\begin{array}{l}\text { Electron cross- } \\
\text { section }\end{array}$ & $\mathrm{cm}^{2}$ & $1.0 \times 10^{-14}$ & $1.0 \times 10^{-13}$ \\
\hline $\begin{array}{l}\text { Hole cross } \\
\text { section area }\end{array}$ & $1 / \mathrm{cm}^{3}$ & $4.5 \times 10^{16}$ & $1.0 \times 10^{12}$ \\
\hline $\begin{array}{l}\text { Uniform total } \\
\text { (Nt) }\end{array}$ & & \\
\hline
\end{tabular}

Limitation on Simulations. All simulations were limited to either thickness, defect at hole transporting (HTM) layer, the density of states (DOS) and different nanoparticles on P3HT host HTM layer. As a result, thermal velocity of electrons and holes were taken as equal at $1 \times 10^{7} \mathrm{~cm} / \mathrm{s}$ while an illumination of $1000 \mathrm{~W} / \mathrm{m}^{2}$, temperature of $25^{\circ} \mathrm{C}$, and an air mass of $1.5 \mathrm{G}$ were adopted and the simulation software was limited to by SCAPS1D simulation software to determine to shortcircuit current density, $\mathrm{J}_{\mathrm{sc}}$, open-circuit voltage, $\mathrm{V}_{\mathrm{oc}}$, fill factor, $\mathrm{FF}$, and power conversion efficiency, $\eta$, for different doped HTM layer. All other simulations were subjected to CST (microwave studio) software.

\section{RESULTS AND DISCUSSIONS}

Influence of $\mathrm{CH}_{3} \mathrm{NH}_{3} \mathrm{Pbl}_{3}$ and $\mathrm{Ag}: \mathrm{CH}_{3} \mathrm{NH}_{3} \mathrm{Pbl}_{3}$ layer thickness. Figure 3 shows the variation of thickness of $\mathrm{CH}_{3} \mathrm{NH}_{3} \mathrm{PbI}_{3}$ and $\mathrm{Ag}: \mathrm{CH}_{3} \mathrm{NH}_{3} \mathrm{PbI}_{3}$ absorber layers with respect to open-circuit voltage.

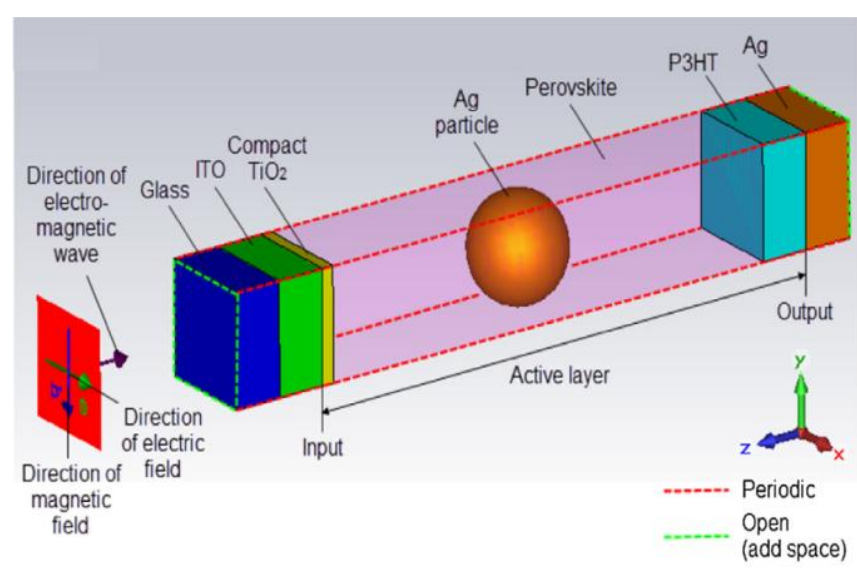

Figure $3-\mathrm{Ag}: \mathrm{CH}_{3} \mathrm{NH}_{3} \mathrm{Pbl}_{3}$ perovskite solar cell model

It can be noted that the open-circuit voltage of $\mathrm{CH}_{3} \mathrm{NH}_{3} \mathrm{PbI}_{3}$ layer increases gradually as thickness increases to a certain peak point. This in effect implies that the efficiency increases up to a certain value which can be considered as the optimum at a specific thickness. Therefore, with increasing thickness, the short circuit current $\left(U_{s c}\right)$ increases and therefore a thicker absorber layer will absorb more photons which in turn, will relatively create more electron-hole pairs resulting in higher open-circuit voltage values. From figure 3 also, it can be observed that a thickness of 320-440 nm is appropriate for $\mathrm{Ag}: \mathrm{CH}_{3} \mathrm{NH}_{3} \mathrm{PbI}_{3}$ perovskite layer for optimal photon absorption based on the AM 1.5G simulation radiation. The optimum thickness that recorded the highest $\mathrm{V}_{\mathrm{OC}}$ for both $\mathrm{Ag}: \mathrm{CH}_{3} \mathrm{NH}_{3} \mathrm{PbI}_{3}$ and $\mathrm{CH}_{3} \mathrm{NH}_{3} \mathrm{PbI}_{3}$ layers was $420 \mathrm{~nm}$. The gradual increase in $\mathrm{V}_{\mathrm{OC}}$ from 280-420 nm was attributed to the plasmonic contributions due to silver nanoparticles with a maximum localized surface plasmonic effect attained at $420 \mathrm{~nm}$. Beyond this thickness, chances of recombination of electron-holes increase as 
the charge carriers traverse the longer distance in thick films and therefore diffusion is hampered. Thickness is a major parameter that plays a vital role in the overall performance of the solar cell. It could be the thickness for the absorber layer, HTM layer or the back contact. However, the efficiency of a perovskite solar cell depends largely on its response to the solar spectrum as influenced by thickness.

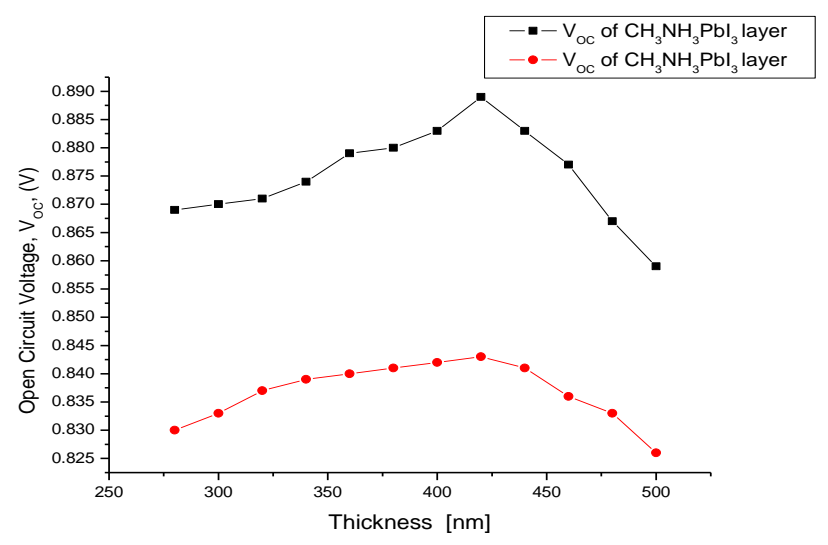
Figure 4 - Influence of thickness on open-circuit
voltage perovskite layer

The thickness of Ag: $\mathrm{CH}_{3} \mathrm{NH}_{3} \mathrm{PbI}_{3}$ absorber layer was varied from $280 \mathrm{~nm}$ to $500 \mathrm{~nm}$ while that of the HTM layer was varied between $28 \mathrm{~nm}$ to 50 $\mathrm{nm}$. The simulated $\mathrm{V}_{\mathrm{OC}}$ was tabulated as shown in figure 1 using table 3 . Thin photovoltaic absorber layers are held responsible for less electron-hole recombination. In such cases, dark saturation current remains very low. This means that opencircuit voltage will remain relatively high. In cases where the thickness is increased, the dark saturation current also increases and as a result, open-circuit voltage decreases and in turn efficiency decreases. Normally, for ideal solar cells, the open-circuit voltage is obtained from (5):

$$
V_{O C}=\left(\frac{A k T}{q}\right) \ln \left(\frac{I_{L}}{I_{O}}+1\right),
$$

where $\mathrm{I}_{0}$ and $\mathrm{I}_{\mathrm{L}}$ are dark saturation current and light-generated current, while $\mathrm{kT} / \mathrm{q}$ and A are the thermal voltage and the photodiode ideality factor [31].

It also implies that the fill factor of this solar cell will decrease as thickness increase and the consequence will be that the cell internally consumes power reducing efficiency after a certain peak thickness. Similar observations were re- ported by the experimental result by [16], who concluded that recombination expedites with increasing thickness.

Influence of Defect State at HTM / perovskite Interface Layer. Methyl ammonium lead triiodide films have a number of defects. These include point defects. A defect layer on the Ag: $\mathrm{CH}_{3} \mathrm{NH}_{3} \mathrm{PbI}_{3} /$ HTM interface layer was considered during simulations which took into account the interface recombinations. The simulation parameters used are shown in Table 4.

Table 4 - Parameters simulating perovskite / HTM layer interface layer

\begin{tabular}{|l|c|c|}
\hline \multicolumn{1}{|c|}{ Interface layer } & Unit & Value/quantity \\
\hline $\begin{array}{l}\text { Capture cross section } \\
\text { electrons }\end{array}$ & $\mathrm{cm}^{2}$ & $1.0 \times 10^{-18}$ \\
\hline Capture cross section holes & $\mathrm{cm}^{2}$ & $1.0 \times 10^{-16}$ \\
\hline $\begin{array}{l}\text { Energy with respect to } \\
\text { reference }\end{array}$ & $\mathrm{eV}$ & 0.050 \\
\hline Integrated total density & $1 / \mathrm{cm}^{2}$ & $1.0 \times 10^{+12}$ \\
\hline
\end{tabular}

Figure 5 shows the effect of interface defect density versus efficiency curves for three different nanoparticle dopants on the HTM layer. From figure 5, it can be noted that there was a negligible effect on efficiency above defect density of $1.12 \times 10^{12} \mathrm{~cm}^{-3}$. When defect density went below $1.01 \times 10^{12} \mathrm{~cm}^{-3}$, a notable decrease in PCEs was recorded.

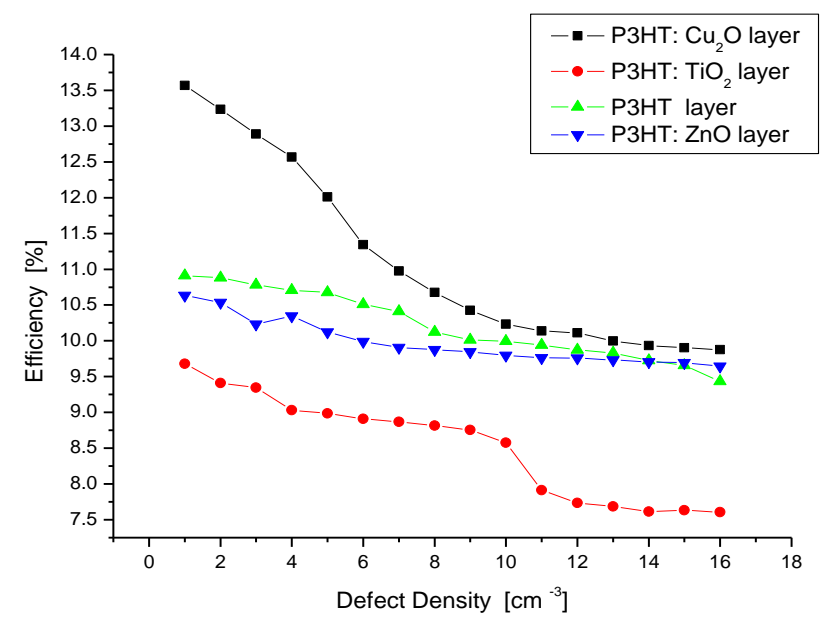

Figure 5 - Defect density of Ag: $\mathrm{CH}_{3} \mathrm{NH}_{3} \mathrm{Pbl}_{3} / \mathrm{HTM}$ interface layer versus efficiency

With an increase in defect density, the recombination rate increases and as a result efficiency decreases. It was noted that doping P3HT layers with binary impurities reduced its potential as a 
HTM layers for hybrid perovskite solar cells. Such attempts have not been carried out through attempts to practically implemented this are on progress. HTM layer can be deposited by sputtering [10], copper oxidation [12, 15], spin coating, atomic layer deposition and even more expensive techniques like molecular beam epitaxial technique.

Influence of Density of State of perovskite Layer. Figure 6 shows the variation of density of state (DOS) with thickness.

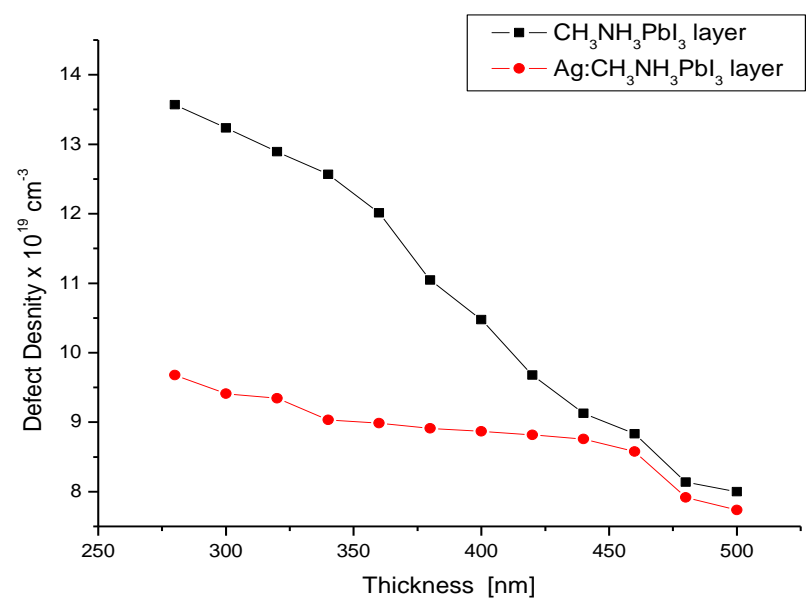

Figure 6 - Defect density of the perovskite layer versus thickness

The effect of DOS of the $\mathrm{CH}_{3} \mathrm{NH}_{3} \mathrm{PbI}_{3}$ perovskite absorber layer was simulated with respect to thickness without accounting on the influence of the doped HTM layers. It can be observed from figure 6 that the density of state $\left(\mathrm{N}_{\mathrm{v}}\right)$ varied from $13.76 \times 10^{19} \mathrm{~cm}^{-3}$ to $7.5 \times 10^{19} \mathrm{~cm}^{-3}$ for $\mathrm{CH}_{3} \mathrm{NH}_{3} \mathrm{PbI}_{3}$ layer and from $9.75 \times 10^{19} \mathrm{~cm}^{-3}$ to $7.79 \times 10^{19} \mathrm{~cm}^{-3}$ for $\mathrm{Ag}: \mathrm{CH}_{3} \mathrm{NH}_{3} \mathrm{PbI}_{3}$ layer. This suggested that as thickness increases, the rate of recombination increases and this introduces multiple parasitic capacitances that negative affect solar cell efficiency.

Influence of Valance band effective density of state on efficiency. Figure 7, 8 show the curves of valance band effective density of state versus efficiency for $\mathrm{CH}_{3} \mathrm{NH}_{3} \mathrm{PbI}_{3}$ and $\mathrm{Ag}: \mathrm{CH}_{3} \mathrm{NH}_{3} \mathrm{PbI}_{3}$ layers. From the curves in figure 6 , it can be noted that in general, the cell efficiency of $\mathrm{CH}_{3} \mathrm{NH}_{3} \mathrm{PbI}_{3}$ absorber layer decreases with the increase in valence band effective density $\left(\mathrm{N}_{\mathrm{V}}\right)$. As the number of holes increases in the $\mathrm{CH}_{3} \mathrm{NH}_{3} \mathrm{PbI}_{3}$ absorber layer. Their possibility of taking part in reverse saturation current once the solar cell circuit is completed also increases. Consequently, the open-circuit voltage declines which leads to low electric conversion efficiency and hence poor solar cell performance.

Since low electron affinity of the HTM layer usually has a great significance on charge carrier mobility low affinity safeguards high-hole mobility. As a consequence, carrier mobility in P3HT as a hole transporting layer increases it as a reliable hole transport material (HTM) for hybrid perovskite heterojunction devices.

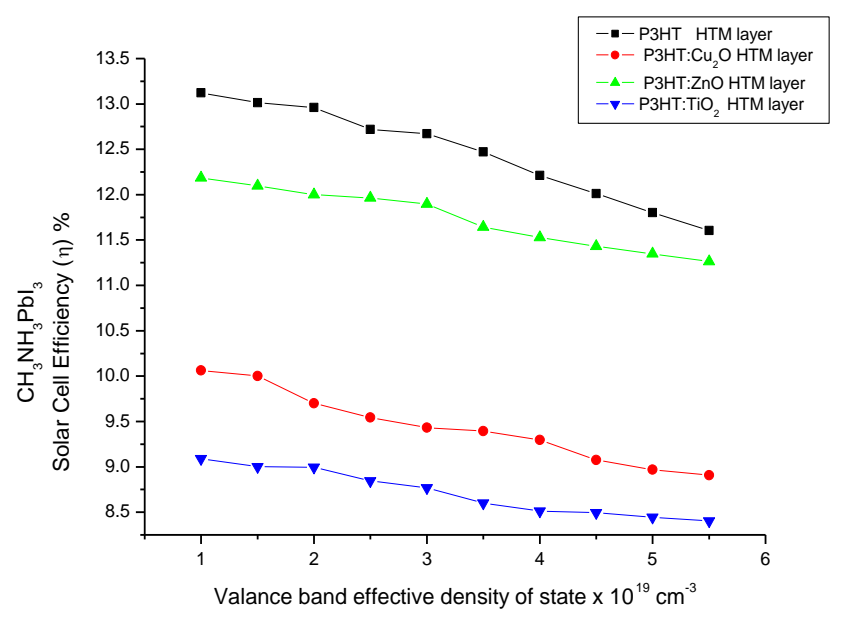

Figure 7 - Valance band effective density of state in $\mathrm{CH}_{3} \mathrm{NH}_{3} \mathrm{Pbl}_{3}$ versus cell efficiency

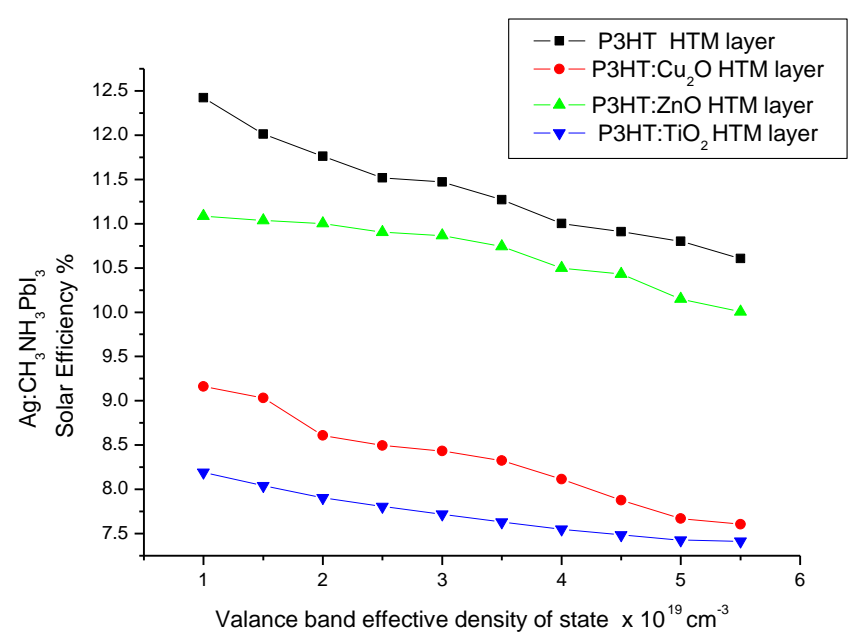

Figure 8 - Valance band effective density of state in $\mathrm{Ag}: \mathrm{CH}_{3} \mathrm{NH}_{3} \mathrm{Pbl}_{3}$ versus cell efficiency

Influence of silver Back Contacts. Simulations were carried out using the silver metal paste as a prospective back contact for methyl ammonium lead triiodide perovskite solar cells to determine the effect of doping P3HT as its hole transport layer. Parameters used in simulating the back contact are as shown in Table 5 while Table 4 illustrates the simulation result of efficiency. It was ob- 
served that the performance of the solar cells decreased depending on the type of nanoparticle material used. $\mathrm{Cu}_{2} \mathrm{O}$ dopant had the highest efficiency while $\mathrm{TiO}_{2}$ dopant had the least efficiency. This showed that doped P3HT was energetically unfavourable for holes to travel towards the silver electrode with an opposing electric field within or close to HTM since the back contact becomes negative.

Table 5 - Parameters for simulating silver back contact

\begin{tabular}{|l|c|c|}
\hline \multicolumn{1}{|c|}{ Parameters } & Unit & Value/quantity \\
\hline $\begin{array}{l}\text { Surface recombination } \\
\text { velocity of electrons }\end{array}$ & $\mathrm{cm} / \mathrm{s}$ & $1.0 \times 10^{+5}$ \\
\hline $\begin{array}{l}\text { Surface recombination } \\
\text { velocity of holes }\end{array}$ & $\mathrm{cm} / \mathrm{s}$ & $1.0 \times 10^{+7}$ \\
\hline Metal work function & $\mathrm{eV}$ & 4.736 \\
\hline $\begin{array}{l}\text { Majority carrier barrier } \\
\text { height relative to } \mathrm{E}_{\mathrm{f}}\end{array}$ & $\mathrm{eV}$ & 0.40 \\
\hline $\begin{array}{l}\text { Majority carrier barrier } \\
\text { height relative to } \mathrm{E}_{\mathrm{v}}\end{array}$ & $\mathrm{eV}$ & 0.3251 \\
\hline
\end{tabular}

The decrease in efficiency was also attributed to the back contact as shown in Table 6 .

Table 6 - Influence of $(\mathrm{Ag})$ back contact

\begin{tabular}{|c|c|c|c|}
\hline HTM Layer & $\begin{array}{l}\text { Thickness } \\
\text { (nm) }\end{array}$ & PCE (\%) & $\begin{array}{c}\% \text { PCE } \\
\text { Decrease }\end{array}$ \\
\hline P3HT & 40 & 13.123 & - \\
\hline P3HT:ZnO & 40 & 10.062 & 3.061 \\
\hline P3HT: $\mathrm{Cu}_{2} \mathrm{O}$ & 40 & 12.184 & 2.939 \\
\hline P3HT: $\mathrm{TiO}_{2}$ & 40 & 9.091 & 4.032 \\
\hline
\end{tabular}

When compared to $\mathrm{Au}$ contact used elsewhere $[17,18,21,28]$, it was anticipated that the lower work function of silver metal contact was attributed to the lower efficiency. It was recommended that $\mathrm{Au}$ should be given a priority when developing hybrid perovskite solar cells.

Numerical Analysis open-circuit voltage. Figure 4 shows a plot of the variation of open-circuit voltage curves for $\mathrm{ZnO}, \mathrm{Cu}_{2} \mathrm{O}$, and $\mathrm{TiO}_{2}$ nanoparticle dopants against P3HT HTM layer varied between 28-50 $\mathrm{nm}$. For purposes of simulation, the thickness of HTM layer was varied between $28-50 \mathrm{~nm}$ at intervals of $2 \mathrm{~nm}$. This thickness is the common thickness is used in many solar cells. The HTM layer containing $\mathrm{ZnO}, \mathrm{Cu}_{2} \mathrm{O}$, and $\mathrm{TiO}_{2}$ nanoparticle dopants in HTM layer were simulated to obtain open voltage currents. Their open-circuit voltages $\left(\mathrm{V}_{\mathrm{OC}}\right)$ were determined as well as their efficiencies. During a simulation, theoretical constants used to estimate opencircuit voltages $\left(\mathrm{V}_{\mathrm{OC}}\right)$ included the fundamental parameters like bandgap, electron affinity, dielectric permittivity, electron, and hole mobility and how they can influence the HTM layers. The optimum open-circuit voltage obtained was as shown in Figure 4.

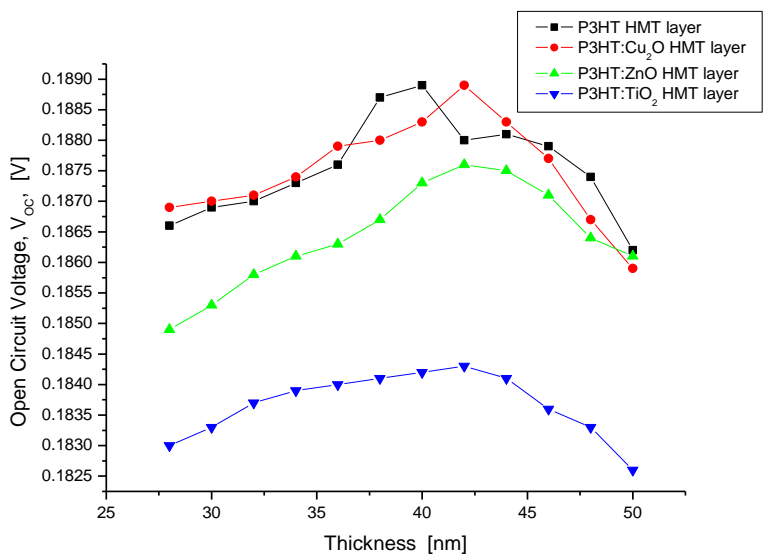

Figure 9 - Influence of HTM thickness on open-circuit voltage

It was observed from Figure 9 that $\mathrm{Cu}_{2} \mathrm{O}$ had a very small significant contribution to the opencircuit voltage on P3HT layer as $\mathrm{V}_{\text {OC }}$ values were relatively close to those of P3HT layer. This suggested that in the presence of P3HT layer, there is no need of introducing $\mathrm{Cu}_{2} \mathrm{O}$ nanoparticles. Its plasmonic contributions can be neglected. The presence of $\mathrm{ZnO}$ nanoparticles relatively reduced the contribution of P3HT layer to open-circuit voltages of the perovskite layer. The reduction was attributed to the higher recombination within the HTM layer as a result of plasmonic effects due to $\mathrm{ZnO}$ nanoparticles. Similarly, $\mathrm{TiO}_{2}$ registered the highest relative reduction of $\mathrm{V}_{\mathrm{OC}}$ as compared to all nanoparticles used. This suggested that its plasmonic contribution acted negatively in P3HT hole transport layer and should be neglected at all costs when developing a perovskite solar cell. These observations were attributed to the unique plasmonic properties of the plasmonic particles used.

Model Ag: $\mathrm{CH}_{3} \mathrm{NH}_{3} \mathrm{Pbl}_{3}$ perovskite solar cell. For modelling and performing simulation using the SCAPS-1D simulator, structure by doping $\mathrm{CH}_{3} \mathrm{NH}_{3} \mathrm{PbI}_{3}$ using silver nanoparticles and also by doping the P3HT hole transport material interfaced with a silver (Ag) metal back contact. Parameters for simulation were adopted from literature, experimental work and simulation using CST (microwave studio) software. 
Table 7 - PC Efficiency of $\mathrm{CH}_{3} \mathrm{NH}_{3} \mathrm{Pbl}_{3}$ perovskite solar cell

\begin{tabular}{|l|c|c|c|}
\hline HTM Layer & $\mathrm{V}_{\text {OC }}(\mathrm{V})$ & Fill Factor & PCE (\%) \\
\hline P3HT & 0.889 & 69.4 & 13.123 \\
\hline P3HT:ZnO & 0.881 & 57.6 & 10.062 \\
\hline P3HT:Cu 20 & 0.885 & 65.3 & 12.184 \\
\hline P3HT:TiO & 0.837 & 52.9 & 9.091 \\
\hline
\end{tabular}

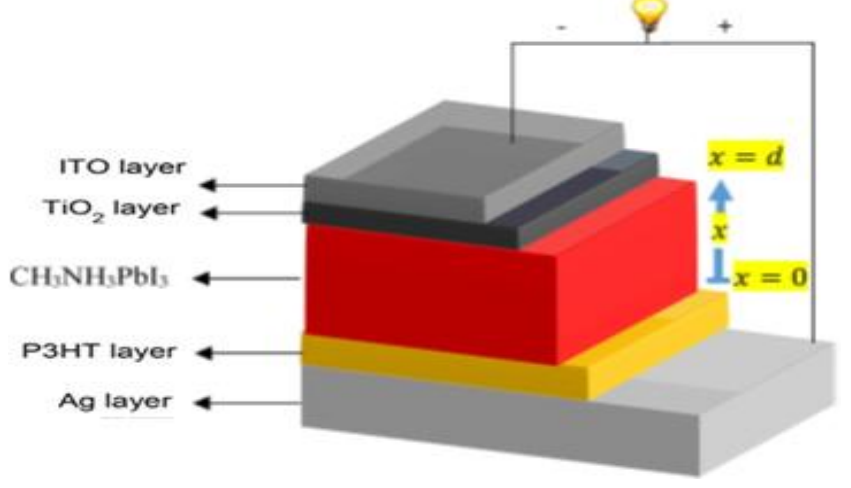

Figure 10 - Model device structure of $\mathrm{Ag}: \mathrm{CH}_{3} \mathrm{NH}_{3} \mathrm{Pbl}_{3}$ perovskite solar cell

Table 8 - PC Efficiency of Ag: $\mathrm{CH}_{3} \mathrm{NH}_{3} \mathrm{Pbl}_{3}$ perovskite solar cell

\begin{tabular}{|c|c|c|c|}
\hline HTM Layer & $\mathrm{V}_{\mathrm{OC}}(\mathrm{V})$ & Fill Factor & PCE (\%) \\
\hline P3HT & 0.843 & 66.4 & 13.033 \\
\hline P3HT:ZnO & 0.841 & 53.6 & 10.002 \\
\hline P3HT: $\mathrm{Cu}_{2} \mathrm{O}$ & 0.842 & 60.3 & 12.114 \\
\hline P3HT:TiO 2 & 0.836 & 48.9 & 9.071 \\
\hline
\end{tabular}

The HTM layer structure suggested here is different from that proposed by other researches where $\mathrm{Ag}: \mathrm{CH}_{3} \mathrm{NH}_{3} \mathrm{PbI}_{3}$ absorber perovskite layer instead of $\mathrm{CH}_{3} \mathrm{NH}_{3} \mathrm{PbI}_{3}$ absorber layer. In all model structures, $\mathrm{Cu}_{2} \mathrm{O}, \mathrm{ZnO}$, and $\mathrm{TIO}_{2}$ were considered as dopant in HTM layer. It was concluded that $\mathrm{Cu}_{2} \mathrm{O}$ ensures the highest performance among dopant nanoparticles slightly lower than P3HT layer. This was attributed to the properties of $\mathrm{Cu}_{2} \mathrm{O}$ since it is a $2.17 \mathrm{eV}$ direct bandgap $p$-type binary inorganic absorber solar cell material
[23]. Starting from P3HT layer through $\mathrm{Cu}_{2} \mathrm{O}$, $\mathrm{ZnO}$ to $\mathrm{TIO}_{2}$ doped layers, the efficiency of 13.123 $\%$ and $9.071 \%$ FF range of $69.4 \%$ to $48.9 \%$ for $\mathrm{CH}_{3} \mathrm{NH}_{3} \mathrm{PbI}_{3}$ perovskite solar cell and $13.033 \%$ and $9.091 \%$ FF range of $66.4 \%$ to $52.9 \%$ $\mathrm{CH}_{3} \mathrm{NH}_{3} \mathrm{PbI}_{3}$ perovskite solar cell.

\section{CONCLUSION}

As compared to other simulated perovskite solar cell efficiencies, the I-V characteristics obtained in this work reflect the performance outcome expected by this perovskite layer of $450 \mathrm{~nm}$ thickness exhibited by a valance band density of states of $3.2 \times 10^{18} \mathrm{~cm}^{-3}$ and interface defect density of $1.12 \times 10^{12} \mathrm{~cm}^{-3}$ respectively. ITO/ $\mathrm{TiO}_{2} /$ $\mathrm{CH}_{3} \mathrm{NH}_{3} \mathrm{PbI}_{3} / \mathrm{P} 3 \mathrm{HT} / \mathrm{Ag}$ perovskite structure gave the best performance among all the PSCs simulated. From the findings of this study, it was revealed that among all the simulated solar cells, the solar cell employing P3HT undoped HTM layer had the best performance. Open-circuit voltage and short circuit current changes were significant. This finding shows that we can modify the performance of a hybrid solar cell by modifying its organic HTM layer using binary inorganic plasmonic nanoparticles. It was therefore concluded that these findings can be used to justify the model in this paper as a potential alternative way to developing conventional hybrid perovskite solar cells. It was recommended that experimental investigation was required to determine its viability. It was concluded that binary inorganic nanoparticles hamper the performance of P3HT HTM layer for solar cell applications.

\section{ACKNOWLEDGEMENT}

The authors acknowledge the Department of Physics of Kenyatta University and Technical University of Mombasa.

\section{REFERENCES}

1. Atwater, H., \& Polman, A. (2010). Plasmonics for improved photovoltaic devices. Nature Materials, 9, 205-213.

2. Barnes, W. L., Dereux, A., \& Ebbesen, T. W. (2003). Surface plasmon subwavelength optics. Nature, 424(6950), 824-830. doi: 10.1038/nature01937

3. Beck, F. J., Polman, A., \& Catchpole, K. R. (2009). Tunable light trapping for solar cells using localized surface plasmons. Journal of Applied Physics, 105(11), 114310. doi: 10.1063/1.3140609

4. Cao, J., Sun, T., \& Grattan, K. T. V. (2014). Gold nanorod-based localized surface plasmon resonance biosensors: A review. Sensors and Actuators B: Chemical, 195, 332-351. doi:

10.1016/j.snb.2014.01.056 
5. Catchpole, K. R., \& Polman, A. (2008). Plasmonic solar cells. Optics Express, 16(26), 21793. doi: 10.1364/oe.16.021793

6. Derkacs, D., Lim, S. H., Matheu, P., Mar, W., \& Yu, E. T. (2006). Improved performance of amorphous silicon solar cells via scattering from surface plasmon polaritons in nearby metallic nanoparticles. Applied Physics Letters, 89(9), 093103. doi: 10.1063/1.2336629

7. Duche, D., Torchio, P., Escoubas, L., Monestier, F., Simon, J.-J., Flory, F., \& Mathian, G. (2009). Improving light absorption in organic solar cells by plasmonic contribution. Solar Energy Materials and Solar Cells, 93(8), 1377-1382. doi: 10.1016/j.solmat.2009.02.028

8. Ghosh, B., Espinoza, G. (2017). Plasmonics for Improved Photovoltaic Devices. Juniper Online Material Science, 1(2): 555-558. doi: 10.19080/JOJMS.2017.01.555558

9. Hu, M., Chen, J., Li, Z.-Y., Au, L., Hartland, G. V., Li, X., ... Xia, Y. (2006). Gold nanostructures: engineering their plasmonic properties for biomedical applications. Chemical Society Reviews, 35(11), 1084. doi: 10.1039/b517615h

10. Kelly, K. L., Coronado, E., Zhao, L. L., \& Schatz, G. C. (2003). The Optical Properties of Metal Nanoparticles: The Influence of Size, Shape, and Dielectric Environment. The Journal of Physical Chemistry B, 107(3), 668-677. doi: 10.1021/jp026731y

11. Kumar, S., Wittenberg, N. J., \& Oh, S.-H. (2012). Nanopore-Induced Spontaneous Concentration for Optofluidic Sensing and Particle Assembly. Analytical Chemistry, 85(2), 971-977. doi: 10.1021/ac302690w

12. Lamprecht, B., Schider, G., Lechner, R. T., Ditlbacher, H., Krenn, J. R., Leitner, A., \& Aussenegg, F. R. (2000). Metal Nanoparticle Gratings: Influence of Dipolar Particle Interaction on the Plasmon Resonance. Physical Review Letters, 84(20), 4721-4724. doi: 10.1103/physrevlett.84.4721

13. Maier, S. A., Brongersma, M. L., Kik, P. G., Meltzer, S., Requicha, A. A. G., Koel, B. E., \& Atwater, H. A. (2003). Plasmonics-A Route to Nanoscale Optical Devices (Advanced Materials, 2001, 13, 1501). Advanced Materials, 15(78), 562-562. doi: 10.1002/adma.200390134

14. Mansoor, R., \& AL-Khursan, A. H. (2018). Numerical modelling of surface plasmonic polaritons. Results in Physics, 9, 1297-1300. doi: 10.1016/j.rinp.2018.04.052

15. Moreno, F., García-Cámara, B., Saiz, J. M., \& González, F. (2008). Interaction of nanoparticles with substrates: effects on the dipolar behaviour of the particles. Optics Express, 16(17), 12487. doi: 10.1364/oe.16.012487

16. Mosiori, C. O., Oeba, D. A., \& Shikambe, R. (2017). Determination of Planck's Constant using Light Emitting Diodes. Path of Science, 3(10), 2007-2012. doi: 10.22178/pos.27-2

17. Murray, W. A., \& Barnes, W. L. (2007). Plasmonic Materials. Advanced Materials, 19(22), 37713782. doi: 10.1002/adma.200700678

18. Oskooi, A. F., Roundy, D., Ibanescu, M., Bermel, P., Joannopoulos, J. D., \& Johnson, S. G. (2010). Meep: A flexible free-software package for electromagnetic simulations by the FDTD method. Computer Physics Communications, 181(3), 687-702. doi: 10.1016/j.cpc.2009.11.008

19. Pattnaik, P. (2005). Surface plasmon resonance. Applied biochemistry and biotechnology, 126(2), 79-92.

20. Petryayeva, E., \& Krull, U. J. (2011). Localized surface plasmon resonance: Nanostructures, bioassays and biosensing - A review. Analytica Chimica Acta, 706(1), 8-24. doi: 10.1016/j.aca.2011.08.020

21. Pillai, S., \& Green, M. A. (2010). Plasmonics for photovoltaic applications. Solar Energy Materials and Solar Cells, 94(9), 1481-1486. doi: 10.1016/j.solmat.2010.02.046

22. Pillai, S., Catchpole, K. R., Trupke, T., \& Green, M. A. (2007). Surface plasmon enhanced silicon solar cells. Journal of Applied Physics, 101(9), 093105. doi: 10.1063/1.2734885 
23. Pirozhenko, I., \& Lambrecht, A. (2008). Influence of slab thickness on the Casimir force. Physical Review A, 77(1). doi: 10.1103/physreva.77.013811

24. Rechberger, W., Hohenau, A., Leitner, A., Krenn, J. R., Lamprecht, B., \& Aussenegg, F. R. (2003). Optical properties of two interacting gold nanoparticles. Optics Communications, 220(1-3), 137141. doi: 10.1016/s0030-4018(03)01357-9

25. Rockstuhl, C., Fahr, S., \& Lederer, F. (2008). Absorption enhancement in solar cells by localized plasmon polaritons. Journal of Applied Physics, 104(12), 123102. doi: 10.1063/1.3037239

26. Schaadt, D. M., Feng, B., \& Yu, E. T. (2005). Enhanced semiconductor optical absorption via surface plasmon excitation in metal nanoparticles. Applied Physics Letters, 86(6), 063106. doi: $10.1063 / 1.1855423$

27. Spinelli, P., van Lare, C., Verhagen, E., \& Polman, A. (2011). Controlling Fano lineshapes in plasmonmediated light coupling into a substrate. Optics Express, 19(S3), A303. doi: 10.1364/oe.19.00a303

28. Stuart, H. R., \& Hall, D. G. (1998). Island size effects in nanoparticle-enhanced photodetectors. Applied Physics Letters, 73(26), 3815-3817. doi: 10.1063/1.122903

29. Tokman, M. D., Westerhof, E., \& Gavrilova, M. A. (2000). Wave power flux and ray-tracing in regions of resonant absorption. Plasma Physics and Controlled Fusion, 42(2), 91-98. doi: 10.1088/0741$3335 / 42 / 2 / 302$

30. Ungureanu, C., Rayavarapu, R. G., Manohar, S., \& van Leeuwen, T. G. (2009). Discrete dipole approximation simulations of gold nanorod optical properties: Choice of input parameters and comparison with experiment. Journal of Applied Physics, 105(10), 102032. doi: $10.1063 / 1.3116139$

31. Willets, K. A., \& Van Duyne, R. P. (2007). Localized Surface Plasmon Resonance Spectroscopy and Sensing. Annual Review of Physical Chemistry, 58(1), 267-297. doi:

10.1146/annurev.physchem.58.032806.104607

32. Xu, G., Tazawa, M., Jin, P., Nakao, S., \& Yoshimura, K. (2003). Wavelength tuning of surface plasmon resonance using dielectric layers on silver island films. Applied Physics Letters, 82(22), 38113813. doi: $10.1063 / 1.1578518$

33. Yee, K. S. (1966). Numerical solution of initial boundary value problems involving maxwell's equations in isotropic media. IEEE Transactions on Antennas Propagation, 14(3), 302-307.

34. Zayats, A. V., \& Smolyaninov, I. I. (2003). Near-field photonics: surface plasmon polaritons and localized surface plasmons. Journal of Optics A: Pure and Applied Optics, 5(4), S16-S50. doi: 10.1088/1464-4258/5/4/353

35. Zhao, D., Ma, Z., \& Zhou, W. (2010). Plasmonic field and efficiency enhancement in crystalline thin film photovoltaics. Next Generation (Nano) Photonic and Cell Technologies for Solar Energy Conversion. doi: 10.1117/12.861887 